\section{Filosofiske kugler}

Joachim Wrang \& Jens Peter Kaj Jensen (red.), Filosofiske kugler - En grundbog i politisk filosofi, Klim, Århus 2001, 231 sider, $275 \mathrm{kr}$.

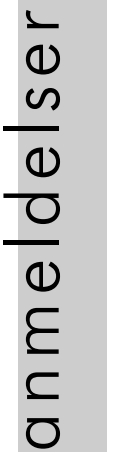

Den politiske tænknings historie nyder for tiden en vis bevågenhed fra de danske forlag, og for forlaget Klim har Joachim Wrang og Jens Peter Kaj Jensen redigeret en påstået "grundbog i politisk filosofi" under titlen Filosofiske kugler. Men nogen grundbog er det ikke. Ikke fordi den er for avanceret til at gøre nytte på grundniveau, ej heller fordi man ikke kan overkomme, at der allerede i første kapitel refereres til "kontraktteori'" (s. 12) og "Hobbes' naturtilstand" (s. 19) uden den mindste antydning af forklaring. Filosofiske kugler kan sikkert læses af begynderstudenter i politisk filosofi, men den savner det systematisk-enhedslige præg, man må forvente af en grundbog. I stedet er det tale om en antologi med bidrag af meget varierende kvalitet fra unge filosoffer og idéhistorikere.

Selv om der er både læseværdige og sågar fremragende artikler iblandt, lider bogen som helhed under to redaktionelle fejlgreb. For det første er der en håbløs mangel på sammenhæng mellem de enkelte kapitler (artikler), hvorved der forspildes åbenlyse anledninger til $\mathrm{i}$ et kapitel at drøfte nogle af de mange problemer, der rejser sig i et andet. Et eksempel kan her hentes fra bogens klart ringeste bidrag, Jesper Richardt Halds "Naturbegreber". Her indledes, rimeligt nok, med forskellige filosoffers opfattelse af naturen og menneskets eventuelle forhold til den, men pludselig fyldes teksten af en ukritisk og floskelfyldt fremlæggelse af Arne Næss' 'økosofi'. I stedet for at tage tråden op fra det foregående kapitel (Wrang: "Politiske ideologier, menneskesyn og intersubjektivitetsteori') og diskutere f.eks. værdien af "det naturlige" - som står tilbage som et meget påtrængende problem efter Wrangs Nietzsche-gennemgang - præsenteres læseren for en omgang 'dybdeøkologisk' vrøvl om overvindelsen af en 'antropocentrisk' naturforståelse. Vrøvl er det, fordi positionen (i hvert fald vurderet ud fra Halds gengivelse) er fyldt med selvmodsigelser, grundløse formodninger og umotiverede argumentationsglidninger. Hvorfor det skulle være godt at forlade antropocentrismen, både $\mathrm{i}$ 'hård' og 'blød' udgave (s. 38), forbliver ubegrundet, ligesom hvad vi kan kalde dybdeøkologiens egen 'biocentrisme', står helt uproblematiseret. Men uproblematisk er den jo ikke, hvis man først har afvist det menneskelige synspunkt som specielt relevant for miljøvurderinger - for hvad er egentlig specielt værdifuldt ved livet, set i naturens universelle perspektiv? Er en livløs planet (Mars, Venus) mindre naturlig end en, hvor der for tiden findes liv (som jorden)? Er dyr og planter mere naturlige, mere værdifulde, end mineraler og kemikalier? Et andet underbelyst problem er glidningen indenfor biocentrismen, hvor det ud fra fremstillingen tydeligt er (patte-)dyrelivet, der har højest værdi, uden at der argumenteres for, hvad der dybdeøkologisk er forkert med en verden overtaget af bakte- 
rielle mikrober. Selvfølgelig sniges den unndgåelige menneskelige målestok for etisk og politisk handling ind med en bemærkning om, at "vi har større forpligtelse for de væsener, som står os nær. Og menneskene står os nærmere end andre levende væsener" (s. 49), men uden skær af begrundelse, hverken for forpligtelsen eller for den biologiske klassifikation. Hald diskuterer ikke, hvordan denne biosfæriske nærhed skal bestemmes for individer, der tilhører forskellige arter, men han kommer med en antydning på s. 38, hvor det hedder: "der er betydende forskelle på dyrearterne, forskelle vi bør tage hensyn til, når vi politisk beslutter eller tillader naturindgreb. Dyr er ikke bare dyr. For eksempel er der afgørende forskel på en pukkelhval, der er et pattedyr med en stor og kompleks hjerne, og en rødspætte, som er en fisk med en lille hjerne. Ligesom der er afgørende forskel på et menneske og en sanglærke." Hvis hjernens størrelse er et afgørende værdikriterium, er det ikke overraskende, at planter og mineraler kommer dårligt ud - men hvorfor det skulle være sådan, synes alt andet end klart ud fra et dybdeøkologisk perspektiv. Det minder snarere om ren og skær antropocentrisme - som det måske ikke er så nemt at overvinde alligevel, hvis man stadig ønsker at sige noget meningsfuldt om miljøværn.

Min kritik af redaktionens arbejde gælder ikke her så meget, at Halds bidrag overhovedet er kommet med (selv om der skal mobiliseres en hel del viljestyrke for igen at rette tæerne ud og læse videre efter dette kapitel), men at Wrang \& Jensen generelt burde have styret de enkelte bidrag strengere. Dels for at sikre, at kapitlerne spiller op til hinanden og viderebehandler allerede opståede problemer (bidragsyderne bør simpelthen læse hinandens bidrag), dels for at sikre, at flest muligt relevante områder inden for den valgte tematik tages op. En behandling af naturbegreber i politisk filosofi er mere og andet end forskellige opfattelser af naturen - det er også værdien af 'det naturlige' (som i 'naturlig autoritet', systemer af 'naturlig prisfastsættelse', råderum for 'naturlige evner'), fundering af politiske love på 'naturlove', civilisation og dannelse i forhold til 'naturfolkenes' tilværelse, etc.

Det andet redaktionelle fejlgreb gælder den tematiske inddeling og inddæmning af de enkelte kapitler. De to første kapitler (Wrangs og Halds) er allerede nævnt. Det tredje, "Køn og ligestilling", er det eneste bidrag fra en kvinde: Cathrine Egeland, men lidt overraskende giver dette forhold ikke anledning til refleksioner i forlængelse af den opfattelse, der tilskrives Rousseau, om, at" $[\mathrm{k}] \varnothing n n e t$ er essentielt for kvinden, men blot en tilfældig egenskab for manden" (s. 64). Mændenes øvrige kapitler har titlerne: "Menneskelige behov, økonomi og frihed", "Klasser og social stratifikation", "Arbejde", "Demokrati", 'Ejendomsret", "Frihed" og "Staten".

Denne kapitelliste afspejler det, der i forordet opstilles som bogens særegne projekt - at være hverken en blot og bar begrebslogisk analyse af centrale begreber $i$ den politiske 
filosofi, eller endnu en historisk, kronologisk fremstilling af den politiske filosofis kongerække. Bogens foretrukne metode beskrives derimod som følger: "Vi har udvalgt forskellige, politisk relevante, filosofiske grundbegreber, og har derefter, hvor det har forekommet rimeligt, undersøgt disses sammenhæng med og betydning for forskellige politiske ideologier. Det er i denne forstand anvendt filosofi, filosofi anvendt på de ideologier, som politikere og politiske tænkere påberåber sig." (s. 8) Originalt eller ej, dette er et prisværdigt forsøg på at beskrive politisk tænkning på en tredje måde. Jeg skal om lidt vende tilbage til, i hvilket omfang det lykkes at indløse den opstillede målsætning, dog uden at kommentere hvert enkelt bidrag. Imidlertid må jeg først knytte en kommentar til redaktionens udvalg af "forskellige, politisk relevante, filosofiske grundbegreber" - nemlig det udvalg der optræder som kapitellisten ovenfor.

Under en bestemt forudsætning kan man nemlig med denne liste i hånden imødegå min tidligere kritik om, at bidragene skulle koordineres bedre og styres til at udfylde hinanden. Denne forudsætning ville være, at bogen havde som opgave at præsentere Karl Marx' politiske tænkning bogens sidste syv kapitler har netop titler, der er filosofiske grundbegreber hos Marx. Og ganske rigtig føres man i hvert af dem på stort set ordentlig vis igennem den marxske teori på det respektive område. Bevares, man får også nyttig og interessant viden om, hvordan tænkere før og efter Marx har konciperet temaet, men det forhindrer ikke, at det tydeligt er Marx' tænkning, der er det teoretiske omdrejningspunkt, og at det er denne, der bliver belyst gennem kapitlernes samlede vinkling. Det er der selvsagt ikke noget forkert i, blot er denne hypotetiske forudsætning ikke nævnt hverken i titel eller forord (der er ingen indledning), hvor man får indtryk af, at det drejer sig om "en grundbog i politisk filosofi", og ikke en historisk belysning af marxske temaer.

Min indsigelse på dette punkt er ikke ment som en forklejnelse af Marx' betydning og indflydelse som politisk tænker, blot vil jeg påpege, at bogen dermed svigter sine egne ambitioner (om at blive en grundbog) ved at sætte unødvendige begrænsninger for sig selv. Tag for eksempel Jens Peter Kaj Jensens kapitel om "Arbejde" - et filosofisk grundbegreb, hvis sammenhæn og betydning for forskellige politiske ideologier skal undersøges. Her forlades hurtigt såvel begrebslogiske, historiske og andre analyser af arbejdsbegrebet til fordel for en koncentration om Marx' fremmedgørelsesproblematik. Dette aspekt er nxppe en helt unaturlig forlængelse af arbejdskategorien og også på mange måder mere interessant. Artiklens problem bliver imidlertid, at diskussionen ikke lader sig udfolde bredt nok inden for den tematiske afgrænsning, som arbejdsbegrebet sætter. Kort sagt: fremmedgørelsesproblematikken er interessant og relevant nok, men fortjener at blive sat i sammenhæng med en mere almen diskussion om identitet, tilhørsforhold og meningsfylde som politisk projekt. 
Hvis man hæver sig op over den marxske arbejdskategoris begrænsninger, kunne fremmedgørelsesproblematikken fjernes fra den ikke voldsomt ophidsende debat om arbejdstid til at inddrage f.eks. den mere aktuelle snak om 'identity politics'. Ikke blot ville artiklen blive mere interessant derved, den ville også have svaret bedre til den i forordet udtalte ambition om at holde "den politiske virkelighed skarpt i fokus". Det kan derfor undre, at det er en af redaktørerne, der forspilder denne oplagte chance.

Heller ikke den anden redaktørs bidrag formår at indfri de løfter, der ligger i bogens målsætning om at støbe de politisk-filosofiske kugler anderledes (deraf bogens titel) ved at smelte "politikken og filosofien sammen som ligeværdige elementer" (s. 7). Wrang anfægter indledningsvis "en klassisk skelnen mellem teoretisk og praktisk filosofi" ved at udpege visse tilsyneladende sammenhænge mellem bestemte metafysiske opfattelser af tiden og bestemte politiske ideologier ('objektiv tid' og 'kapitalismens arbejdsbegreb', 'subjektiv tid' og anarkisme, 'cirkulær tid' og økologisk tænkning). Åbenbart er dette blot ment som eksempler på, at der er en forbindelse mellem teoretisk og praktisk filosofi, men desværre til ingen nytte, siden der ikke gøres forsøg på at bestemme, hvad der eventuelt kendetegner den. Detville ellers have været rigtigt interessant, specielt i lyset af, at Egeland benytter netop en skarp skelnen mellem teoretisk og praktisk filosofi ("ontologisk" og "politisk" begrebssammenhæng, s. 57) som strukturerende princip for for- ståelsen af forholdet mellem kønnene. Igen må man efterlyse et nærmere samarbejde og en tættere koordinering af bidragene. Wrang går i stedet over til det mere håndterlige spørgsmål om forholdet mellem politiske ideologier og menneskesyn, men heller ikke her opnår vi den eftertragtede "legering" (s. 7) mellem politik og filosofi. Efter en meget kort og skematisk opstilling af liberalismens og socialismens menneskesyn som hhv. individualistisk uafhængighed og mellemmenneskelig afhængighed, præsenteres vi for et katalog over forskellige filosoffers 'intersubjektivitetsteorier'. Dette kata$\log$ falder i to dele, som man må formode skal svare til de to politiske ideologiers menneskesyn - centreret hhv. om 'den ene' (Husserl, Heidegger, Sartre, Kierkegaard og Nietzsche) eller om 'den Anden' (Buber, Lévinas, Foucault). Men det bliver ved formodningen, for der gives ingen analyse af den antagne signifikante sammenhæng. Udbyttet bliver en god håndfuld skitser af visse tænkere set $\mathrm{i}$ forhold til et begreb om 'intersubjektivitet' mens bogens proklamerede særegne metode dermed synes forfaldet til blot en mere vilkårlig udgave af den "politiske almendannelse på højt niveau", som man i forordet beskyldte den politisk-filosofiske kongerække for at være.

De fleste af bogens kapitler ender netop som sådanne simple oversigter over den teoretiske forståelse, som udvalgte medlemmer af kongerækken har af et bestemt emne (der, som nævnt, står centralt i Marx' politiske tænkning). Det skal dog retfær- 
digvis siges, at flere af dem giver bedre oversigt og er mindre overfladiske end Wrangs; fremhæves kan Peter Bjørntofts klasse-kapitel, Frank Jørgensen om ejendomsret og Søren Rossen om staten. Disse kapitler er udmærkede som orienterende skitser over et områdes forskellige teoridannelser, men at de skulle repræsentere nogen form for anderledes filosofisk kuglestøbning er svært at se. Det samme gælder Egeland om køn og ligestilling, som ellers adskiller sig fra de andre bidrag med et noget mere avanceret teoretisk begrebsapparat. Alligevel er det ikke sproget, der i dette kapitel vil forstyrre bogens grundbogsambitioner, men snarere hendes forvirrende og frustrerende praksis med at organisere præsentationen omkring en række filosofiske primærpositioner, samtidig med der overvejende bygges på og henvises til en sekundærlitteratur, hvis status, gehalt og sammenhæng står ukommenteret.

Alt $i$ alt kommer bogen til at svigte sit metodologiske program såvel som sine målgruppeambitioner, bl.a. på grund af den manglende samog bearbejdning af de forskellige bidrag. Et kapitel som alle bidragsydere (inkl. redaktørerne) burde læse som et eksempel til efterfølgelse er således Ulf Vincent Olsens "Menneskelige behov, økonomi og frihed". Her er nemlig et kapitel, der faktisk indfrier løftet om en legering af politik og filosofi, og som på glimrende vis introducerer til forskellige tænkeres teorier indenfor et emne, hvis afgrænsning er underbygget og velmotiveret. Kapitlet er krystalklart disponeret ud fra tre umid- delbart forståelige behovssituationer, hentet fra afrikanske skabelsesmyter. Dermed gives en almenmenneskelig forståelsesramme, der samtidig virker arketypisk strukturerende for den historiske gennemgang af en række relevante teoridannelser (kynikerne, stoikerne, epikureerne, Smith, Malthus, Ricardo, Marx, Galbraith og Gbadegein). Disse præsenteres kort, præcist og prægnant, med klart overblik over de væsentlige momenter og med nådeløst fravalg af informationer, der er af mindre saglig interesse. Dermed gives en vedkommende, filosofisk belyst og politisk relevant forståelse af behovsproblematikken, der på samme tid er historisk velbegrundet og aktuel. Havde blot resten af bogen holdt samme niveau som Olsens kapitel, ville den have været meget anbefalelsesværdig som en grundbog i politisk filosofi.

Knut Anton Bockman

\section{Alt er som bekendt ... romantik \\ Lis Møller og Marie-Louise Svane (red.), Romanticism in Theory, Aarhus Universitetsforlag, Àrhus 2001, 272 sider, 298 kr.}

I romantikken sammentænker man litteratur, kunst, filosofi, sprogteori, psykologi, politik og naturvidenskab: Alt er for romantikerne romantik. Det var vi måske godt klar over. At også en hel del af det, vi i dag som moderne eller senmoderne mennesker mener og 